\title{
Study on the Time Management and Self-controlled Learning of Students in Local Colleges and Universities in Transition
}

\author{
Jianing Zhang \\ School of Economics and Management \\ Changchun University of Technology \\ Changchun, China
}

\author{
Hailong Zhang \\ Division of Planning \& Development \\ Changchun University of Technology \\ Changchun, China
}

\begin{abstract}
In recent years, China not only pays attention to the construction of project "double first-rate" but also emphasizes the cultivation of applied technology talents when building the higher education system. In 2014, the Ministry of Education of the People's Republic of China proposed to guide a number of colleges and universities to transform to universities of applied sciences in order to establish a multitiered applied technology talent structure. Local colleges and universities have responded to the national call and adapted to the development trend. The applied technical talents have high practical ability and outstanding creativity, and are at a pivotal position in the national innovation system. The university stage is a critical period for students before finally move to the workplace. Reasonable time management and scientific selfcontrolled learning can not only improve academic performance, but also have a huge positive impact on future career development. This paper analyzes the problems and puts forward suggestions for improving college students' time management and self-controlled learning ability based on the transformation from local colleges and universities to universities of applied sciences.
\end{abstract}

Keywords-local colleges and universities; technologyapplied; time management; self-controlled learning; talent cultivation

\section{INTRODUCTION}

With the rapid development of higher education in China in recent years, the process of popularization of higher education has been accelerating, but the development of local colleges and universities has hit a plateau period. At the same time, China is in a critical period of economic restructuring and looking for new economic growth points. It has also promulgated a series of important documents such as "Made in China 2025" to promote the development of manufacturing talents. Therefore, the transformation of local universities to universities of applied sciences will not only meet the objective needs of the economic and social development of China, but also benefits their own further development.

The university is the major stage of learning before students enter the society, and is also the most precious youth time of life. However, the time utilization of universities of applied sciences students is not optimistic, which seriously lacks the sense of time value and selfcontrolled learning consciousness. Under the perspective of cultivating applied technology talents, the level of time management and self-controlled learning ability of local universities of applied sciences determines the quality of personnel training, which is the premise and foundation for innovative and entrepreneurial talent cultivation. Based on this, this paper puts forward some suggestions for local colleges and universities to improve the students' time management and self-controlled learning ability in the transition period of universities of applied sciences.

\section{THE INEVITABLE TREND OF LOCAL COLLEGES AND UNIVERSITIES TRANSITION TO UNIVERSITIES OF APPLIED} \section{SCIENCES}

\section{A. Conforms to the Objective Needs of Economic and Social Development}

"Population-Education-Economy" is a system of interdependent and coordinated development. The development of higher education affects the number, structure and quality of the population. The social responsibility of local colleges and universities is to serve the development of local economy and society, cultivate and transport a large number of high-quality talents, realize the transformation of scientific and technological achievements, promote local social and cultural development, and build high level talent pool. According to statistics, in the group of workforce, technology talents accounts for $40 \%$ in Japan, Germany as high as $50 \%$, while China only accounts for $5 \%$. There are nearly 10 million high-tech talent gaps in China by 2017. [1] The transformation of some local colleges and universities, especially the newly-built local universities into universities of applied sciences, can effectively help countries solve the problem of the lack of skilled technical talents in the process of industrial restructuring. "The Belt and Road", "Made in China 2025", "Industry 4.0" and other real economy also need to applied technology talent support, called for speeding up the pace of development of modern occupation talent in China. 


\section{B. Conforms to the Law of Higher Education Development}

Universities of "985" project, "211" project and "double first-rate" project are the leading ranks of higher education in China and have certain academic prestige both at home and abroad. However, the real principal part of higher education in China is local colleges and universities. After the enrollment expansion in higher education institutions in 1999, many vocational colleges have merged and upgraded to colleges and universities, which brought new challenges to the development of local colleges and universities. Compared with the traditional key universities, the local colleges and universities have been in the middle level of higher education for a long time in China, lacking in both historical and academic precipitation. Compared with the vocational colleges, local colleges and universities lack the original high-level practical skills. Only by transforming as soon as possible can breakthroughs be achieved, and get more options in admissions. "Applied technology talent" belongs to the type of talent division but do not represent the education level, and every level of higher education can be "application oriented" or "academic oriented". Higher vocational colleges may not be able to output skillful applied technology talent if they are not cultivated well. The local colleges and universities grasp the opportunity to transformation and change the training mode, and then we can cultivate more qualified applied technology talents.

Active transformation also helps solve the structure and social demand of higher education and higher education does not adapt, blindly rising thousands school all in the same side, the problem of inaccuracy is expected to effectively promote the university personnel training mode reform. Initiative transformation also helps to solve the problem that the structure of higher education does not meet the needs of society and the blind standard of higher education. It is expected to break the employment market on graduates employment and enterprise hiring difficult coexistence cycle. Effectively promote the reform of talent cultivation mode in colleges and universities, so that restrict the students' innovation spirit and practical ability and long-term training quality difficulties, then consistent with the law of development of colleges and universities.

35 pilot universities of applied sciences set up an Association of Universities (Colleges) on June 28, 2013, and the quantity of member is continuously increasing. We should strengthen cooperation and coordination in the region, realize the combination of many colleges and universities, integrate the practical training bases with geopolitical advantages, and mutually benefit sharing, so as to reduce duplication and improve resource utilization. Colleges and universities need to strengthen practical and applied research, with reference to the accurate positioning of the real needs of the industry and enterprises. Not only should we meet needs of enterprises, but also can inspire the development of colleges and universities. International mutual recognition of bachelor's degrees and vocational qualifications has become a trend. For example, China became an official member of the "Washington Accord" in mutual recognition of international Bachelor's degree in engineering in 2016. This not only laid the foundation for Chinese engineering students to go international, but also meant that Chinese higher education really head to the world. Talents from universities of applied sciences in developed countries have occupied an important position in various industries over the world. However, Chinese universities of applied sciences have just begun to step onto the stage and the transformation of local universities is an inevitable trend.

\section{THE CHARACTERISTICS AND CURRENT SITUATION OF College STUdents' Time MANAGEMENT AND SELF- CONTROLLED LEARNING}

\section{A. The Characteristics of Time Management and Self- controlled Learning of College Students}

Time management is a kind of concept, it is also a method to make good use of limited time more effectively then realize the meaningful and joyful life. Time management has received extensive attention to contemporary society, Stephen Richards Covey divided the theory of time management into four generations: The first generation focuses on the use of memos and notes of time management; the second generation emphasizes on calendars and schedules, noting the importance of planning for the future; the third generation theory emphasizes the important things, setting short-term, medium-term and long-term goals according to priorities, and then one by one to develop plans to strive for the highest efficiency; the fourth generation focus on personal management, emphasizing to change the quality of life, to achieve a meaningful and happy life.[2] Time management of college students is the application of time management theory in university life and is an important part of time management. Einstein once said: "The difference between people lies in their free time". How to make good use of the four-year period of university is actually how to carry out effective individual selfmanagement.

Self-controlled learning has the intrinsic motivation of self-excitation. Learners can be aware of the results of the study by regular and effective learning schedule, and keep a keen ability of improving physical and social environment. In the aspect of meta cognition, learners are active participants of motivation and behavior. [3] The ability of College Students' self-controlled learning is the ability to learn new knowledge and adapt to the environment through independent thinking, self-motivation, self-practice, selfreflection, and then sum up experience. The main contents include: a) set the correct learning goals; b) programme the learning plan; c) self-monitoring and restraint in the learning process; d) self-assessment and evaluation of learning outcomes.

\section{B. The Status of Student Time Management and Self- controlled Learning of Universities of Applied Sciences}

Universities of applied sciences students generally lack the sense of time value, as well spend a lot of time on recreation and slack off in their studies. They cannot make correct time management independently, and let the university study and life and work without any planning; lack of the awareness about self-controlled learning, poor 
ability to use autonomous learning tools, and not willing to try new learning tools. Most students find it difficult to summarize their own knowledge systems during so many college subjects study. The history and academic level of universities of applied sciences are generally not good. Now, most teachers in universities of applied sciences are young teachers who lacking teaching experience, and the quality of student source is poor. Finally, the graduates will find it hard to gain a foothold in the job market.

\section{SETTING UP THE ENVIRONMENT FOR IMPROVING TIME MANAGEMENT AND SELF-CONTROLLED LEARNING ABILITY}

\section{A. Empolder a Suitable Path for the Development of Applied Technology University Teachers}

The majority of local colleges and universities belong to the definition of teaching-oriented University, and there is a large part of them upgraded from higher vocational colleges after 1999, with significantly nature of occupational and technological. Universities of applied sciences education system focused on the undergraduate level. Local universities of applied sciences which characterized by local service, application and technology are in urgent need of setting new teaching and training environment. The goal of cultivating talents in universities of applied sciences is to train applied talents who are suitable for social and economic development. These talents need guidance from both applied teachers and "double qualified" teachers. The training about "spirit of craftsman" of teachers can improve teaching ability and practice the excellence of work. They also can answer questions in the process of student self-controlled learning or point direction. Boyer who is the former President of the Carnegie Foundation put forward "Domains of Scholarship" in "Scholarship Reconsidered: Priorities of the Professorate", which changed the previous situation of "academic" as a "research" in the narrow sense, and considered the academic includes "Scholarship of Discovery", "Scholarship of Application", "Scholarship of Integration" and "Scholarship of Teaching".[4] The majority of teachers are young teachers in universities of applied sciences compared with the research university who lacking of teaching ability, so they should be trained in accordance with the colleges' characteristics. Improve teachers' ability of application through qualification and assessment ways after the training of teachers. Empoldering a suitable path for the development of applied technology university teachers is setting up the environment for improving time management and selfcontrolled learning ability of students.

\section{B. Establish a Student-centered Classroom Education}

Today is a learning society, we must strive to live and learn. In the traditional teaching process and academic research, teachers are generally the main body and teaching is often the object of study. Students' self-learning behavior is always easily overlooked. Primary and middle school's teaching limited to books, we can regard it as a successful class if no one have question at the end; on the contrary, triggering interest in learning and deep thinking of students is the successful teaching during university, and the following learning needs multiple channels of autonomous learning, rather than only rely on classroom education. Therefore, it is more important to guide students' learning methods than teach knowledge directly. Providing direction and various self-controlled learning resources is more useful than limited to books. The effective integration of knowledge between subjects will bring new insights to the original research, and cannot be limited to the original division of discipline. We should return the right of self-controlled learning to students and adhere to "less and better" in classroom teaching, leave time to students so that students can show themselves. Provide a variety of learning content and evaluation methods to encourage students to explore the unknown field and provide scientific research support.

Students can share academic hot spots in WeChat public account or other APP, then guide teachers and students to discuss extensively in the message area. Especially successful discussions can gather information and form offline open class. According to professional characteristics and personal preferences, students can choose different content and time courses so that mobilizes the enthusiasm for learning. Start higher level of precision teaching and the real learner-centered by using big data, build specialized school big data center based on reliable data so that feedback the students' real learning situation, and gradually improve learning performance. Each college should prepare MOOCs courses actively, not only to help freshman feel the university teaching environment in advance, but also facilitate students to study independently and let students become the master of the class.

\section{SugGESTIONS ON STUdENT TIME MANAGEMENT AND SELF-CONTROLLED LEARNING ABILITY PROMOTION}

The time management of universities of applied sciences students should cover all the time emphasizes the division of the spare time and the class time no longer. In response to the call of "mass entrepreneurship and innovation", what's more, training of innovative and entrepreneurial talents successful is closely related to training and improving the self-controlled learning ability of students. Autonomous learning is an internalization process for students to consciously accept theoretical knowledge and absorb in oneself; innovation and entrepreneurship practice is the process of externalizing knowledge.

Self-controlled learning is to change the traditional mode of education, so that students can put forward the problem and solve the problem. Only by correct time management can make students have enough time to learn independently; high quality self-controlled learning can enhance students' ability of thinking and self-control, prompting students to conduct scientific time management. Time management and self-controlled learning are complementary to each other, and one kind of ability's promotion will promote the progress of the other. The following are specific proposals: 


\section{A. Change Professional Training Programs, Emphasize the New Model of Integration of Production and Teaching}

The speciality provision and training plan of applied technology universities should strictly meet the needs of local economic, both social and cultural development, and take employment as a guide to change original disciplinary classification. Colleges and universities must have some academic precipitation and research atmosphere, but not focus on academic research like "double first-rate" universities, nor is it a mere "employment skills training", gradually emphasizing both theoretical knowledge and practical ability. The integration of production and education, cooperation between school and enterprise represents a new school-running mode and talent cultivating mode. Paying attention to the requirements of industries and enterprises is both pressure and motivation. The close cooperation between both parties can stimulate the students' time management and self-learning capability to further enhance.

\section{B. Take Effective Cohesive Education and Strengthen Pre- school Preparation Activities}

Education in excessive stage is called cohesion education, which is a guidance education on transition stage of the two level school gives students learning and life. The poor cohesion of the course leads to the inability of students to invest in new life quickly. Establish a high school-university alliance allows prospective college students to contact college courses early before go to school, and let students have interest in their own major. Some students may find that they have no interest in his profession and can understand the rules and regulations of transfer major in advance. Different from the "Bridging course" in western countries, the cohesion education mentioned in this paper only let students choose courses and life knowledge they want to contact independently in advance, so that they can learn for a short period and avoid being caught napping. The "campus opening day", which is widely carried out in Chinese colleges and universities, is a manifestation of the cohesion education. It is a pity that such activities are not enough in-depth. It is difficult to meet the requirements of "education", and it needs to be further deepened. In the future, it is still necessary to develop a systematic cohesion education, lay the foundation for time management and self-controlled learning.

\section{Strengthening the Guarantee of Self-controlled Learning and Setting up a Communication Center of Independent Learning}

Colleges and universities should actively publish policies to encourage students independent learning and development, such as the improvement of the library, classrooms and other places of hardware and software facilities. Develop "implement opinion about strengthen students" selfcontrolled learning", and stipulate that each student must take 1-2 electives credits of network courses. Put forward "methods of innovative and entrepreneurial support and incentive for universities of applied sciences students" to motivate students. We should reform student management system, such as use credit system instead of academic year system, give students more choices in terms of time and form Make use of characteristics of College Students' behavior, such as conformity, obedience, altruism and diligence, so as to enhance the initiative of autonomous learning.

We can setting up independent learning exchange center. Schools and teachers only play the role of supervision, give full play to students' subjective initiative, strengthen face-toface communication, share the experience of time management and self-controlled learning, and help mobilize students' enthusiasm of self-controlled learning.

\section{Provide a Network Learning Platform and Promote the Use of Fragmented Time}

In network age, internet has become a part of people's life in every field. It's also an indispensable tools for learning. The new learning methods and ways based on the Internet has a great impact on the individual. Such as network course, overturning course and fragmented learning, which is convenient for students to choose the time and place according to the individual condition and content of learning, benefit students and teachers. The border between classroom learning and extracurricular learning even disappear. Fragmented time usually refers to scattered, irregular, and not planned time. Actually, it can be used as a small attention unit. In order to improve the comprehensive quality and ability of college students, it is necessary to integrate the time of debris and make use of the spare time to increase the disposable time.

Universities need to hold lectures related to MicroCourse, MOOCs and Flipped Classroom, by inviting wellknown scholars to publicize self-learning information. Set up information technology application courses to carry out network knowledge and skills training, so that improve students' network ability. At the same time, we can make use of information technology to promote teaching reform. So that promote the sharing of high quality teaching resources, and establish a mixed teaching model based on students' independent learning. We should enrich the online learning resources library by external introducing, teachers' internal developing, and teacher-student cooperation. As long as we filter strictly, we will ensure the authority and legitimacy of students' learning resources. Finally, guide students to carry out the correct network of independent learning and improve self-learning evaluation system. Enhance the network of moral and legal awareness is also the key point, we have to guide students to resist bad information.

\section{E. Reshape the Sense of Time Value and Enhance the Awareness of Efficacy}

The sense of time value refers to a stable attitude and concept of driving time with motivation or direction, which is the foundation of individual time management. When applied technology university students lose the sense of time value, they cannot understand the meaning of time in learning and personality development correctly, and even lead to the loss of goals. It is possible to establish a "systembased" time management education system, such as launching a series of time values education activities, trying 
lectures, essay contests and speech contests to attract teachers and students. We can establish a systematic course about oriented time management education system. For example, carry out a series of time value education activities to attract teachers and students to participate, such as special lectures, essay contest and speech contest. Universities can set up an elective course of time management, guide applied technical university students establish the concept of value and concentrate on learning. Emphasizes the efficiency consciousness at the same time, to take good use of every seconds while studying and working, and cannot be lost in the atmosphere of "pretend to work hard".

\section{F. Start the Tutorial System for Undergraduates and Teach Students in Accordance with Their Aptitude}

The diversified development of students' individuality has always been a difficult problem to be solved, and the comprehensive development of students has become a breakthrough point. The whole undergraduate tutorial system can develop students' own ability to learn and solve problems, establish the correct values and make a reasonable university study life planning through professional enlightenment education, scientific research competition, project design and graduation thesis (design) in different stages. Ordinary classroom education is a teacher help dozens or even hundreds of students, the tutor system can effectively reduce the ratio of students to teachers and get more meticulous teaching. In addition to completing the homework of ordinary class, students also need to complete the assignment of the tutor on time, it improve the ability of time management and self-controlled learning virtually.

\section{CONCLUSION}

Actually, time management education has been exists in Chinese universities, but it almost appears in the entrance education or ideological and political education by means of lectures. The content of it is mostly personal experience, can hardly arouse college students' interest and continuous attention. Compared with the time management training in vocational education, the emphasis on time management education in local applied technology undergraduate colleges is obviously insufficient, so it is urgent to bring it into the curriculum education system. At the same time, selfcontrolled learning provides students with an innovative platform to bring students' innovative consciousness and learning ability into full play, and promote knowledge content to be reflected in practical activities. How to improve the time management and self-controlled learning ability of applied university students more effectively, moreover, requires more comparative studies and empirical analysis to support it.

\section{REFERENCES}

[1] Zhao xiuhong,Liu bozhi. The Gap of Advanced Mechanic Is Nearly 10 Million, Where Does "Chinese Craftsman" Come From[N]. China Education Daily, 2017-3-15(1).
[2] Stephen Richards Covey(1989). The Seven Habits Of Highly Effective People (Wang chibing Trans)[M]. Beijing: China Youth Publishing Group, 2008.

[3] Zimmerman B J, Risemberg R. Self-Regulatory Dimensions of Academic Learning and Motivation[A]. Phye G D.Handbook of Academic Learning. Academic Press, 1997:105-125

[4] Boyer, E. L. Scholarship Reconsidered: Priorities of the Professoriate[Z]. The Carnegie Foundation for the Advancement of Teaching, 1990. 